\title{
Inhibition of RET tyrosine kinase by SU5416
}

\author{
Luca Mologni ${ }^{1}$, Elisa Sala ${ }^{1,5}$, Sara Cazzaniga ${ }^{1}$, Roberta Rostagno ${ }^{1}$, Thomas Kuoni ${ }^{3}$, \\ Miriam Puttini ${ }^{1}$, Jenny Bain ${ }^{4}$, Loredana Cleris ${ }^{5}$, Sara Redaelli ${ }^{1}$, Barbara Riva ${ }^{1}$, \\ Franca Formelli ${ }^{5}$, Leonardo Scapozza ${ }^{3}$ and Carlo Gambacorti-Passerini ${ }^{1,2}$
}

\author{
${ }^{1}$ Department of Clinical Medicine, Prevention and Biotechnology, University of Milan-Bicocca, Monza, Italy \\ ${ }^{2}$ Department of Oncology, McGill University, Montreal, Canada \\ ${ }^{3}$ Laboratoire de Chimie Therapeutique, School of Pharmaceutical Sciences, University of Geneva, Geneva, Switzerland \\ ${ }^{4}$ MRC Protein Phosphorylation Unit, School of Life Sciences, University of Dundee, Dundee, Scotland, United Kingdom \\ ${ }^{5}$ Department of Experimental Oncology, Istituto Nazionale Tumori, Milan, Italy \\ (Requests for offprints should be addressed to L Mologni at Department of Clinical Medicine and Prevention, DIMEP, University of Milan-Bicocca, via Cadore 48, 20052 Monza, Italy; \\ Email: luca.mologni@unimib.it)
}

\begin{abstract}
Thyroid neoplasia is frequently associated with rearranged during transfection (RET) proto-oncogene mutations that cause hyperactivation of RET kinase activity. Selective inhibition of RET-mediated signaling should lead to an efficacious therapy. SU5416 is a potent inhibitor of vascular endothelial cell growth factor receptor, c-Kit, and FLT-3 receptor tyrosine kinases presently used in clinical trials. We found that SU5416 inhibits RET with similar potency, both in cell-free assays and in cells, thus causing proliferation arrest in oncogenic RET-transfected cells and in papillary thyroid carcinoma (PTC) cells expressing the RET/PTC1 oncogene, but not in RET-negative control cells. SU5416 inhibited RET-mediated signaling through the extracellular signal regulated kinase (ERK) and JNK pathways. In addition, we show that a naturally occurring MEN2 mutation at codon 804 confers resistance to SU5416, but not to the related compound SU4984. We provide a possible explanation to these results by using molecular docking. Finally, SU5416 was also assessed against an array of 52 tyrosine and serine/threonine kinases.
\end{abstract}

Journal of Molecular Endocrinology (2006) 37, 199-212

\section{Introduction}

Thyroid cancer represents approximately $1 \%$ of all neoplasms (Gimm 2001). Incidence in Western countries is about three cases out of 100000 people. Several histological types of thyroid malignancy are recognized: papillary (PTC), follicular, poorly differentiated, and anaplastic thyroid carcinoma; all arise from follicular cells. Medullary thyroid carcinoma (MTC) originates from parafollicular C-cells.

PTCs are the most frequent cancers of the thyroid gland, accounting for about $80 \%$ of all cases (Santoro et al. 2004). About $30-40 \%$ of sporadic and up to $85 \%$ of radiation-induced PTCs are associated with genomic rearrangements of the RET locus that lead to the expression of constitutively activated RET/PTC fusion tyrosine kinases (Nikiforov et al. 1997, Putzer \& Drosten 2004). As rearranged during transfection (RET)/PTC expression is already found in small, indolent nodules, it is believed to be a very early event in thyroid carcinogenesis. Current therapy for PTC is based on surgical removal of the thyroid gland followed by radioiodine therapy and thyroid hormone administration, which can cause a number of undesired effects.
Point mutations of RET are responsible for the onset of both sporadic and familial forms of MTC (Ichihara et al. 2004). All individuals affected by multiple endocrine neoplasia type 2 syndromes (MEN2A and MEN2B) harbor germ line RET mutations. These patients develop MTC in all cases, plus pheochromocytoma and hyperparathyroidism with variable penetrance, in addition to other symptoms, which are reported in a minority of cases. Similar to PTC, the treatment of choice for MTC relies on surgical intervention. While hereditary MTC is diagnosed at an early stage, sporadic MTC is characterized by a high recurrence rate; more than $50 \%$ of patients eventually die of their disease.

Tumor- or gene-specific therapies are thought to be the most promising alternatives to the present chemotherapy or radiotherapy regimes. Different strategies have been devised to achieve selectivity, which includes immunotherapy (Powell et al. 2003), gene therapy (Drosten \& Putzer 2003), ribozymes (Parthasarathy et al. 1999), and small-molecule inhibitors. The last option is well represented by the remarkable success of Imatinib in the treatment of chronic myeloid leukemia and gastrointestinal stromal tumors (Kadomatsu et al. 
1997, Kantarjian et al. 2002). Given that a certain oncogene is a primary early event and is necessary for tumor cell survival, but could be dispensable for normal cells, blockage of its action is instrumental to a successful therapy. A few small-molecule inhibitors of RET have been identified so far, which demonstrated growth inhibition of cells expressing RET oncogenes (Carlomagno et al. 2002a,b, 2003, Lanzi et al. 2003, Strock et al. 2003).

SU5416 is a 3-substituted indolin-2-one compound that was discovered as a vascular endothelial cell growth factor receptor (VEGFR) inhibitor (Sun et al. 1998) and is currently undergoing clinical evaluation as an antiangiogenesis drug for a number of solid tumors (Glade-Bender et al. 2003). More recently, SU5416 has been shown to inhibit other tyrosine kinases, such as FLT3, c-Kit, and c-MET (Krystal et al. 2001, Yee et al. 2002, Wang et al. 2004), while it is inactive against epidermal growth factor receptor (EGFR), human epidermal growth factor receptor 2 (HER2), insulin-like growth factor 1 receptor (IGF1R), and platelet-derived growth factor receptor (PDGFR). Phase II clinical trials are ongoing with the compound as a FLT-3 inhibitor in patients with advanced acute myelogenous leukemia (AML) (Fiedler et al. 2003).

In this study, we found that SU5416 blocks RET kinase activity. We show that cell growth and downstream signaling promoted by RET/PTC oncogene are prevented by SU5416.

\section{Materials and methods}

\section{Cells and reagents}

All cell culture media were supplemented with $100 \mathrm{U} / \mathrm{ml}$ penicillin, $100 \mu \mathrm{g} / \mathrm{ml}$ gentamicin, and $2 \mathrm{mM}$ Gln. Murine pro-B cell line Ba/F3 was maintained in RPMI medium with $10 \%$ fetal bovine serum (FBS), plus CHO-conditioned supernatant as a source of IL-3. Three $\mathrm{Ba} / \mathrm{F} 3$-derived cell lines expressing RET/PTC2 (hereafter referred to as $\mathrm{Ba} / \mathrm{PTC}$ ), NMP/ALK (Ba/NA, Coluccia et al. 2004) and BCR/ ABL (Ba/BA, Piazza et al. 2005) were generated by transfection of the corresponding fusion cDNA and selection of stable transfectants with $1 \mathrm{mg} / \mathrm{ml}$ G418. These cells were kept in RPMI plus 10\% FBS without IL-3. PTC cells, TPC-1, and NPA were grown in Dulbecco's modified Eagle's medium (DMEM) containing $10 \%$ FBS. Parental NIH-3T3 and NIH-3T3 cells stably transfected with RET/PTC2 (NIH-PTC2) and RET $^{\mathrm{V} 804 \mathrm{M}}$ mutant (NIH-V804M) were cultured in DMEM with $10 \%$ (parental cells) or $5 \%$ FBS. Insect cell line Sf9 was kept at $27^{\circ} \mathrm{C}$ in SF900-II medium (Invitrogen) with $10 \% \mathrm{FBS}$ and $0 \cdot 1 \%$ Pluronic F-68.
Antibodies were used in western blotting according to recommended dilutions. Anti-HisG antibody (Invitrogen) is directed against the 6xhistidine tag followed by a glycine. Anti-RET (C-19, Santa Cruz Biotechnology, Santa Cruz, CA, USA) recognizes the short isoform of wild-type RET; anti-phospho-RET (recognizing phosphotyrosine 905 of wild-type RET), anti-phosphoJNK1/2 (which detects active diphosphorylated (Thr183/Tyr185) JNK1 and JNK2) and anti-JNK1/2 antibodies were from Cell Signaling Technology (Danvers, MA, USA). Anti-phosphotyrosine (4G10) was purchased from Upstate Biotechnology (Charlottesville, VA, USA); anti-ERK1/2 and anti-phospho-ERK1/2 (Thr183/Tyr185) were from Sigma; anti-p21/WAF1 (Ab-1) and anti-p27 (C-19)-G antibodies were bought from Merck Biosciences (Darmstadt, Germany) and Santa Cruz Biotechnology respectively.

SU5416 was purchased from Calbiochem, dissolved in dimethyl sulfoxide (DMSO), aliquoted and stored at $-20{ }^{\circ} \mathrm{C}$ until used.

\section{Production of recombinant proteins and in vitro kinase assay}

Human FLT-3 (amino acids (aa) 589-993, EntrezGene accession number NP_004110), ABL (aa 230-517, isoform a, NP_005148) and RET (aa 700-1020, NP_066124) kinase domain cDNA sequences were cloned in $\mathrm{pHis}^{\mathrm{E}}$ baculovirus transfer vector (Mologni et al. 2005), in BamHI/SalI, KpnI/XbaI and KpnI/SalI restriction sites respectively. Mutant V804M RET was obtained from wild-type RET plasmid by site-directed mutagenesis using the QuikChange kit (Stratagene, La Jolla, CA, USA), according to manufacturer's instructions, with the following mutagenic primers: sense, GGCCCGCTCCTCCTCATCATGGAGTACGCCAAATACGGC, and antisense, GCCGTATTTGGCGTACTCCATGATGAGGAGGAGCGGGCC (the nucleotide corresponding to the missense mutation is underlined). ALK sequence was cloned in pBlueBacHis2C vector (Invitrogen) as described (Donella-Deana $e t$ al. 2005). The sequence of all inserts was verified by DNA sequencing. Recombinant proteins were expressed in Sf9 cells with an amino terminal hexa-histidine tag to aid in purification, as described (Mologni et al. 2005). Briefly, proteins from total lysate were fractionated in a DEAE-sepharose column and positive fractions were identified by anti-HisG western blotting, loaded on a nickel-chelate affinity column and eluted with imidazole. The initial anion-exchange step is required to achieve homogeneity in the final preparation. Activity of purified kinase domains was verified by radioactive autophosphorylation assay: a reaction mix containing $0.5 \mu \mathrm{g}$ recombinant enzyme, $5 \mu \mathrm{M}$ cold ATP, $1 \mathrm{mM}$ DTT, $10 \mu \mathrm{Ci}\left[\gamma_{-}^{-32} \mathrm{P}\right]$ ATP, $25 \mathrm{mM}$ Hepes pH 7.5, $10 \mathrm{mM}$ $\mathrm{MgCl}_{2}$, and $10 \mathrm{mM} \mathrm{MnCl}{ }_{2}$ was incubated at $30^{\circ} \mathrm{C}$ for 
$15 \mathrm{~min}$. The reaction was stopped by adding Laemmli buffer and heating at $95^{\circ} \mathrm{C}$ for $5 \mathrm{~min}$. The samples were resolved on a $10 \%$ SDS-PAGE gel and proteins were transferred to an Immobilon ${ }^{\mathrm{TM}}-\mathrm{P}$ membrane and visualized by autoradiography.

\section{In vitro kinase assays}

ELISA kinase assay was performed as described (Mologni et al. 2005), using approximately 1 pmol recombinant enzyme and $1 \mathrm{nmol}$ peptide-substrate, assuring Michaelis-Menten assumption that the substrate is in vast excess with respect to the enzyme. Peptide substrates used include RET activation loopderived peptide (SRDVYEEDSYVKRSQGRIPVK, for RET kinase) and ALK activation loop-derived mutant peptide (Donella-Deana et al. 2005) in which Tyr 1282 and 1283 were replaced by phenylalanine (ARDIYRASFFRKGGCAMLPVK, used with ALK, ABL, and FLT-3 kinases). For non-radioactive autokinase assay, the recombinant enzyme was incubated for $15 \mathrm{~min}$ at $30^{\circ} \mathrm{C}$ in kinase buffer $(25 \mathrm{mM}$ Hepes, $\mathrm{pH} 7 \cdot 0,1 \mathrm{mM}$ $\mathrm{MnCl}_{2}$, and $5 \mathrm{mM} \mathrm{MgCl}$ ) in the presence of $6.5 \mu \mathrm{M}$ ATP, with or without inhibitors. The reaction was stopped by adding Laemmli buffer and the sample was loaded on SDS-PAGE, transferred to a nitrocellulose membrane and detected with anti-phospho-RET or anti-HisG antibodies.

\section{Inhibitor specificity profiling}

Radioactive kinase assays were performed at room temperature in the presence of substrate peptides, $\left[\gamma^{3}{ }^{3} \mathrm{P}\right] \mathrm{ATP}$, and $10 \mu \mathrm{M}$ SU5416, using recombinant kinases obtained from various expression systems. Procedures for purification and assay of 30 of the 52 kinases have been described (Davies et al. 2000, Bain et al. 2003). The other enzymes will be described elsewhere. Kinase assays were performed using ATP concentrations close to the $K_{\mathrm{m}}$ value for each kinase. All protein kinases were grouped accordingly into three categories, namely 5,20 , and $50 \mu \mathrm{M}$ ATP.

\section{Proliferation assay and growth curve}

Serial dilutions of kinase inhibitor were prepared in cell culture medium with $1 \%$ FBS in 96-well plates. Cells were then resuspended in 1\% FBS medium and added to the plate at $10^{4}$ cells/well. Cell proliferation was measured at $72 \mathrm{~h}$ using the tritiated-thymidine incorporation assay as described previously (Gambacorti-Passerini et al. 1997). Each data point was done in triplicate.

For growth curves, $\mathrm{Ba} / \mathrm{F} 3$ and $\mathrm{Ba} / \mathrm{PTC}$ cells were seeded $\left(10^{5} /\right.$ well $)$ in 24 -well plates in triplicate and treated with DMSO or various concentrations of SU5416. Every 2nd day, the cells were counted by Trypan Blue exclusion assay, diluted to keep them in logarithmic growth phase, and fresh inhibitor was added.

\section{Western blot analysis of cell extracts}

$\mathrm{Ba} / \mathrm{PTC}$ cells were grown overnight in $1 \% \mathrm{FBS}$ and treated with SU5416 or DMSO for $4 \mathrm{~h}$. They were then washed with PBS and lysed in $1 \times$ Laemmli buffer $(62 \cdot 5 \mathrm{mM}$ Tris-HCl, $\mathrm{pH} 6 \cdot 8,2 \%$ SDS, $10 \%$ glycerol, and $0 \cdot 3 \mathrm{M} \beta$-mercaptoethanol). Total lysates corresponding to $3 \times 10^{5}$ cells were loaded on SDS-PAGE, transferred to nitrocellulose membrane and probed with anti-RET and anti-phospho-RET antibodies.

TPC-1 cells $\left(6 \times 10^{6}\right)$ were seeded in $100 \mathrm{~mm}$ cell culture dishes, grown overnight in 1\% FBS and treated with SU5416 or DMSO. Cell lysates were prepared after washing with PBS, by scraping the cells in lysis buffer (25 mM Tris-HCl, pH 7.9, $150 \mathrm{mM} \mathrm{NaCl}, 1 \%$ NP-40, $1 \mathrm{mM}$ EDTA, $2 \mathrm{mM}$ EGTA, $10 \mathrm{mM} \mathrm{NaF}, 1 \mathrm{mM} \mathrm{Na} \mathrm{VO}_{4}$, $1 \mathrm{mM}$ DTT, $1 \mathrm{mM}$ PMSF, $1 \mu \mathrm{g} / \mathrm{ml}$ leupeptin and aprotinin) and incubating for $40 \mathrm{~min}$ on ice. The lysates were then centrifuged for $30 \mathrm{~min}$ at 13000 r.p.m. at $4{ }^{\circ} \mathrm{C}$ and total protein content of the supernatants was measured by Bradford assay. Equal amounts $(100 \mu \mathrm{g})$ of total protein were loaded on SDS-PAGE and analyzed by western blotting using phospho-specific antibodies.

\section{Soft-agar growth assay}

NIH-PTC-L cells were seeded in six-well plates at 10000 cells/well in a medium containing $0.33 \%$ low melting agar (type VII, Sigma) and either DMSO or $20 \mu \mathrm{M}$ SU5416, on a layer of $0.5 \%$ agar, as described (Borrello et al. 1996). Fresh inhibitor was added every 3 days to the top layer. The colonies were counted after 15 days.

\section{Cell-cycle analysis}

Cells were seeded in six-well plates at a density of $2 \times 10^{5}$ /well and treated with inhibitor or vehicle. Cells were harvested at 24,48 , and $72 \mathrm{~h}$ after treatment, washed with PBS and fixed in $70 \%$ ethanol at $-20{ }^{\circ} \mathrm{C}$. The samples were then centrifuged and resuspended in PBS containing $50 \mu \mathrm{g} / \mathrm{ml}$ propidium iodide and $100 \mu \mathrm{g} / \mathrm{ml}$ RNase A, incubated at $37^{\circ} \mathrm{C}$ for $30 \mathrm{~min}$ and analyzed by FACScan flow cytometer (Beckton Dickinson, Franklin Lakes, NJ, USA).

\section{ATP competition assay}

Increasing doses of ATP $(0 \cdot 011-2 \cdot 4 \mathrm{mM})$ were incubated with RET in the presence of DMSO, or 0.05 , $0 \cdot 25$, and $1 \cdot 25 \mu \mathrm{M}$ SU5416, and an ELISA kinase assay was performed as described (Mologni et al. 2005). ATP binding curves were then calculated for each inhibitor concentration and plotted using the Lineweaver-Burke method. 


\section{In vivo target modulation}

Female CD-1 nu/nu mice (7-9 weeks old) were supplied by Charles River (Calco, Como, Italy) and kept under standard laboratory conditions according to the guidelines of the Istituto Nazionale Tumori (INT), Milan, Italy. Animal studies were approved by the Ethics Committee for Animal Experimentation of INT. Mice were implanted subcutaneously with NIH-PTC cells $\left(10^{6}\right.$ cells $/$ mouse $)$. When the tumors were measurable, the mice received an acute i.p. dose of $50 \mathrm{mg} / \mathrm{kg}$ SU5416 in $60 \mu \mathrm{l} \mathrm{DMSO,} \mathrm{or} \mathrm{DMSO} \mathrm{alone.} \mathrm{Mice} \mathrm{were}$ sacrificed $6 \mathrm{~h}$ after treatment and their tumors resected and snap frozen on liquid nitrogen. Tumor mass was minced in lysis buffer and lysates were then prepared as described earlier. Equal amounts of total protein were loaded on $8 \%$ SDS-PAGE and visualized by western blot with anti-RET and anti-phospho-RET antibodies.

\section{Molecular modeling}

A model of the tertiary structure of RET tyrosine kinase domain in an active conformation was built by homology modeling, using the phosphorylated active insulin receptor kinase domain (Protein Data Bank entry, 1IR3) as a template. The amino acid sequence similarity between RETand insulin receptor kinase domains is $57 \%$. The model was refined using AMBER 6 software (Case et al. 1999) for computing molecular dynamic simulations. The model of V804M mutant RET was built by changing Val-804 of wild-type RET model into a methionine; local side chain minimization was then performed with tripos force field and Powell method, with a convergence criterion of $0.05 \mathrm{kcal} / \mathrm{mol}$, using Sybyl 7·0 (Anonymous). The binding mode of SU5416 to wild-type and V804M mutant RET was evaluated by molecular docking, using GOLD algorithm (Tripos Inc., St. Louis, MO, USA) (Jones et al. 1997).

\section{Statistical analysis}

Data were always generated in triplicate and mean \pm s.D. is reported on graphs. Dose-response curves were normalized over the vehicle control and analyzed by non-linear regression using Graph Pad PRISM 4.0 software. $\mathrm{IC}_{50}$ data are reported as the global fitting of at least three independent experiments, with $95 \%$ confidence interval (CI).

\section{Results}

\section{SU5416 inhibits RET kinase activity in vitro}

A series of compounds sharing a 2-indolinone core structure was screened for RET inhibition in an in vitro ELISA-based kinase assay, using the recombinant enzyme and an exogenous peptide as a substrate. In a previous work, we reported the activity of two of these compounds (Mologni et al. 2005). SU5416 (Fig. 1) belongs to the same family of inhibitors and was therefore tested in our assay. SU5416 inhibited RET with an $\mathrm{IC}_{50}$ of $170 \mathrm{nM}$, using $300 \mu \mathrm{M}$ ATP (Fig. 2A). In the same experimental conditions, the compound showed a similar degree of inhibition on FLT-3 kinase, a well-known SU5416 target, while it was much less active against $\mathrm{ABL}$ and $\mathrm{ALK}$ kinases (Table $1 ; \mathrm{IC}_{50}$ values from three or more experiments are reported with $95 \%$ CI. In order to confirm the data, we performed an autophosphorylation assay of recombinant RET (Fig. 2B). Significant inhibition was already seen at $0 \cdot 1 \mu \mathrm{M}$, supporting the finding that SU5416 is a RET inhibitor. The same membrane was stripped and developed with anti-HisG antibody to show that similar amounts of protein have been loaded.

To determine the mechanism of inhibition, an ATP competition assay was performed, based on the ELISA kinase assay. ATP dose-response curves in the presence of different inhibitor concentrations showed that the $V_{\max }$ is not altered by the compound, whereas the $K_{\mathrm{m}}$ for ATP increased with increasing inhibitor concentration (Fig. 2C). A secondary plot of the data from Fig. 2C showed a linear correlation between the slopes of the curves and the inhibitor concentrations (data not shown). These results suggest competition between SU5416 and ATP and are in agreement with virtual docking data showing that SU5416 binds within the ATP-binding pocket (see below). Moreover, doseresponse experiments performed at different ATP doses indicated that the $\mathrm{IC}_{50}$ of the compound increased progressively from $0.05 \mu \mathrm{M}$ (at $11 \mu \mathrm{M}$ ATP) to over $6 \mu \mathrm{M}$ (with $3 \mathrm{mM}$ ATP), again indicating an ATP-competitive behavior (data not shown). The calculated $K_{\mathrm{i}}$ of compound SU5416 for RET was $13 \mathrm{nM}$.

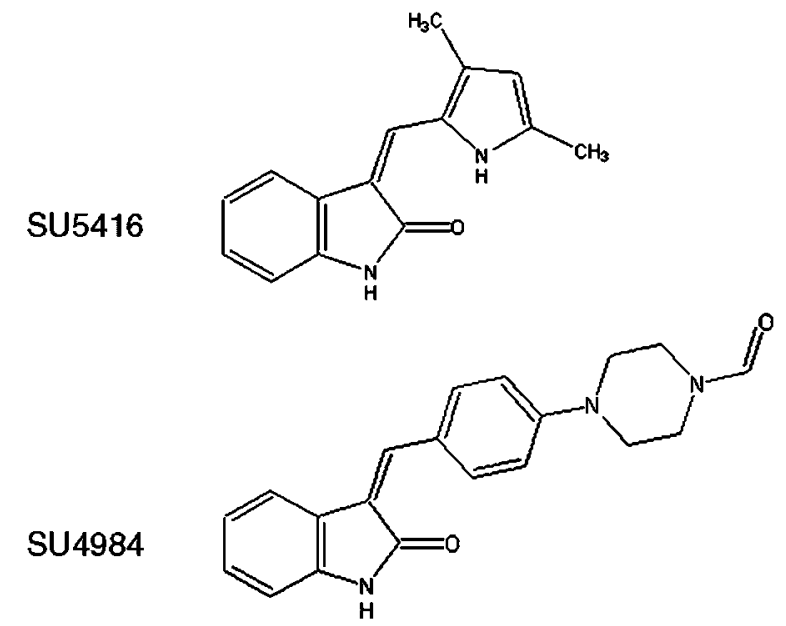

Figure 1 Chemical structures of the compounds used in this work, SU5416 and SU4984. 

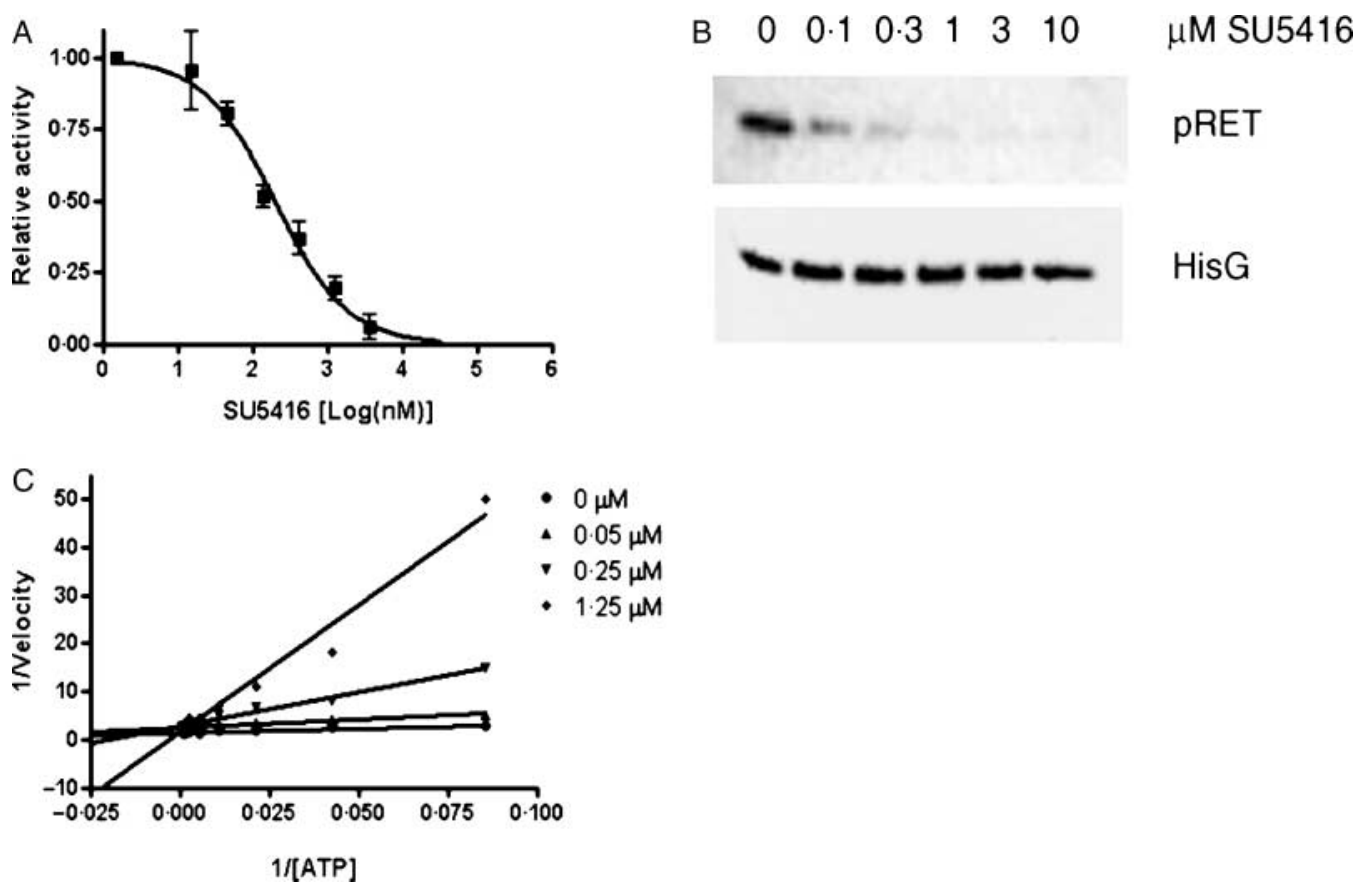

Figure 2 Inhibition of RET kinase activity by SU5416. Recombinant RET kinase domain was incubated with increasing concentrations of SU5416 and kinase activity was detected: (A) as peptide substrate phosphorylation by ELISA; (B) as autophosphorylation by anti-phosphotyrosine-905 western blotting (upper panel); anti-HisG western blot is shown in the lower panel as a loading control; (C) kinetics of RET inhibition showing competition of SU5416 with ATP. The kinase reaction was performed with increasing ATP concentrations in the presence of different SU5416 doses. The data are shown by Lineweaver-Burke plot.

\section{Inhibition of RET-mediated transformation}

Having established SU5416 as a good inhibitor of RET in cell-free conditions, we sought to determine whether the compound would be toxic to RET oncogeneexpressing cells. Murine pro-B cell line Ba/F3 needs exogenous IL-3 for growth and is commonly exploited to study the transforming ability of oncogenes. We selected a stably transfected $\mathrm{Ba} / \mathrm{F} 3$ clone expressing RET/PTC2 (Ba/PTC). These cells grow independently of IL-3 (Fig. 3A) and show constitutive high levels of tyrosine-phosphorylated proteins (data not shown). $\mathrm{Ba} / \mathrm{PTC}$ cell growth was blocked by the treatment with $2 \mu \mathrm{M} \mathrm{PP1}$, a known RET inhibitor (Carlomagno et al. 2002b) (Fig. 3A). Compound SU5416 blocked the proliferation of $\mathrm{Ba} / \mathrm{PTC}$ cells in a dose-dependent manner, with an $\mathrm{IC}_{50}$ of $7 \cdot 9 \mu \mathrm{M}(95 \% \mathrm{CI}, 6 \cdot 8-9 \cdot 1 \mu \mathrm{M})$, while sparing parental $\mathrm{Ba} / \mathrm{F} 3$ cells (Fig. 3B). The observed proliferation arrest correlated with a strong inhibition of RET/PTC2 phosphorylation, as shown by anti-phospho-RET western blot of total lysates (Fig. 3C). Densitometric analysis of phosphorylated bands revealed an $\mathrm{IC}_{50}$ of approximately $5 \mu \mathrm{M}$, consistent with proliferation data. RET expression level was not affected by the treatment, as shown in the lower panel of Fig. 3C. In line with the results obtained in ELISA, the treatment with SU5416 only marginally affected the proliferation of NPM/ALK- and BCR/ABL-transfected $\mathrm{Ba} / \mathrm{F} 3$ cells, which showed $\mathrm{IC}_{50}$ values between 30 and $40 \mu \mathrm{M}$ (data not shown). A time-course experiment was carried out by exposing $\mathrm{Ba} / \mathrm{F} 3$ and $\mathrm{Ba} / \mathrm{PTC}$ cells to SU5416 for 10 days. The growth of $\mathrm{Ba} / \mathrm{PTC}$ cells was progressively delayed with increasing SU5416 concentrations, while $\mathrm{Ba} / \mathrm{F} 3$ cells were not affected (Fig. 3D).

Another cellular model frequently used for oncogene studies is represented by NIH-3T3 murine fibroblasts. The expression of RET/PTC oncogenes induces anchorage-independent growth (Carlomagno et al. 2002a) and morphological changes in NIH-3T3 cells. Moreover, while parental NIH-3T3 cells grow as a monolayer, RET/PTC-transfected cells are not

Table 1 Inhibition of tyrosine kinase activity by SU5416

IC50 $(\mu \mathrm{M})(95 \% \mathrm{Cl})$

\section{KINASE}

RET

FLT-3

ABL

$0 \cdot 17(0 \cdot 14-0 \cdot 21)$

$0 \cdot 16(0 \cdot 13-0 \cdot 19)$

$11(10-13)$

$1 \cdot 2(0 \cdot 8-1 \cdot 8)$ 

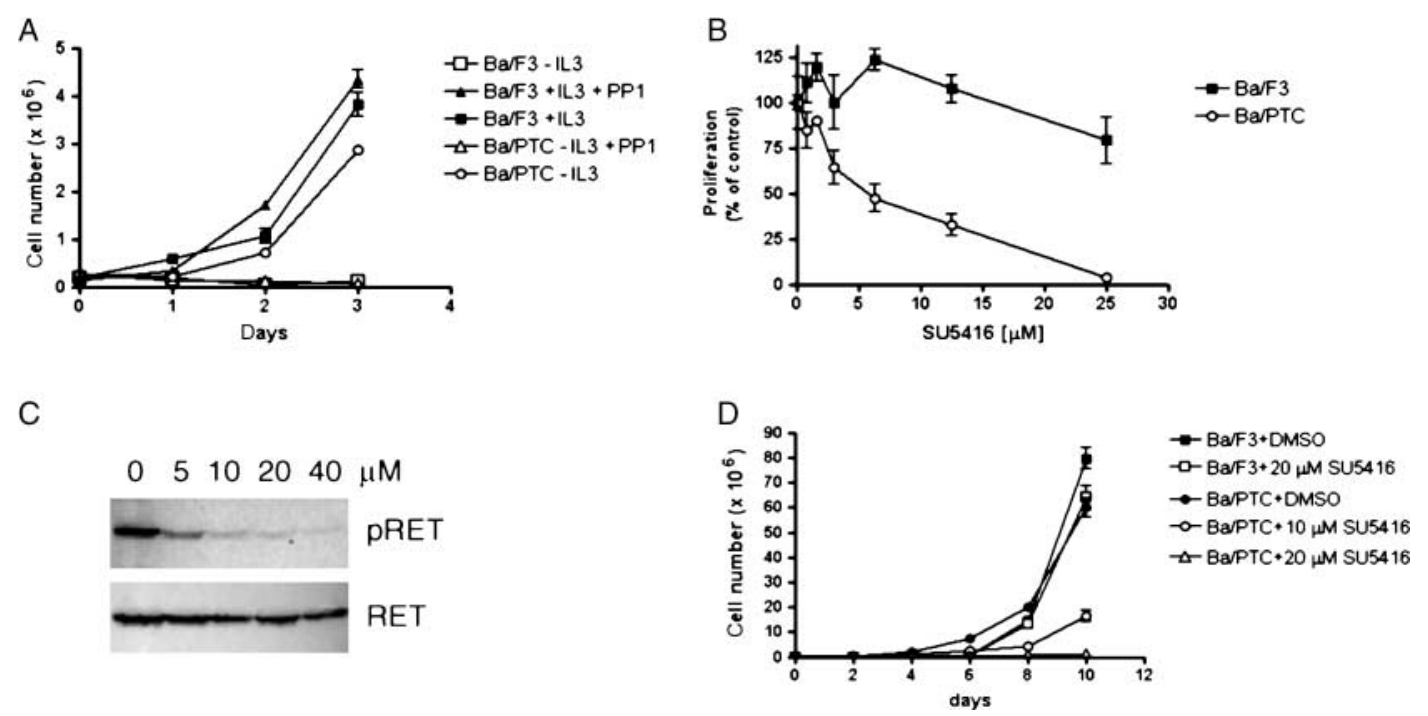

Figure 3 Inhibition of RET-transformed Ba/PTC cells: (A) Growth curves of Ba/F3 parental cells and RET/PTC2 stable transfectants Ba/PTC, with and without IL-3 and PP1; (B) Dose-response curves of SU5416 in a ${ }^{3} \mathrm{H}-$ thymidine uptake assay of $\mathrm{Ba} / \mathrm{F} 3$ and $\mathrm{Ba} / \mathrm{PTC}$ cells. DMSO-treated controls are set as $100 \%$; (C) Analysis of $\mathrm{Ba} / \mathrm{PTC}$ total lysates, after $4 \mathrm{~h}$ treatment with SU5416 at the indicated concentrations. Western blot was developed with anti-phospho-RET ${ }^{\mathrm{Y} 905}$ (top panel) and anti-RET (bottom panel) antibodies. (D) Time course of Ba/F3 and $\mathrm{Ba} / \mathrm{PTC}$ cells without (black symbols) and with different SU5416 doses.

inhibited by cell contact and form foci. Inhibition of RET kinase activity restores the parental phenotype (Carlomagno et al. 2002b). We treated NIH-PTC2 cells with $10 \mu \mathrm{M}$ SU5416, causing complete RET inactivation, as shown by the lack of activation loop phosphorylation (Fig. 4A). After $48 \mathrm{~h}$ of SU5416 treatment, the morphology of cells reverted to a flattened, non-dense appearance (Fig. 4D), similar to parental cells (shown in Fig. 4B), indicating blockage of RET tyrosine kinase signaling. In contrast, DMSOtreated cells maintained a transformed phenotype (Fig. 4C). NIH-PTC2 cells treated with SU5416 were no longer able to grow in soft agar medium (Fig. 4F), or form transformation foci (data not shown). These data suggest that SU5416 is able to abrogate the transforming potential of the RET/PTC2 oncogene.

\section{Effects of SU5416 on human papillary carcinoma cells}

TPC-1 cells are derived from PTC and express the RET/PTC1 fusion kinase. The proliferation of TPC-1 cells was inhibited in the presence of SU5416 (Fig. 5A), with an $\mathrm{IC}_{50}$ of $2 \cdot 7 \mu \mathrm{M}(95 \% \mathrm{CI}, 2 \cdot 3-3 \cdot 2 \mu \mathrm{M})$. In contrast, NPA, a RET-negative papillary carcinoma cell line, was much more resistant to the treatment, showing $50 \%$ inhibition at $40 \mu \mathrm{M}$. The proliferative block of TPC-1 cells correlated at the molecular level with a complete shut off of RET/PTC1 Tyr-905 phosphorylation, after $8 \mathrm{~h}$ treatment (Fig. 5B). Tyr-905 (numbering refers to wild-type RET) is a main switch of RET catalytic activity. When phosphorylated, it stabilizes the open conformation of the activation loop, thus allowing substrate entry into the active site. It is therefore considered to be a hallmark of RET kinase activation (Kawamoto et al. 2004). As SU5416 induced inactivation of RET/PTC1 kinase, we investigated whether downstream signaling pathways were affected by the treatment. RET oncogenes have been shown to activate a number of proliferative and anti-apoptotic signals, including the RAS/ERK and the JNK pathways (Chiariello et al. 1998). In TPC-1 cells treated with SU5416 for $36 \mathrm{~h}$, a reduction of both ERK1/2 and JNK1/2 phosphorylation was observed, concomitantly with a block of RET/PTC1 phosphorylation (Fig. 5C). Relative phosphorylation inhibition of p44 and p42 ERK was 90 and $75 \%$ respectively, as determined by densitometric analysis of the bands. The phospho-JNK signal in treated cells was reduced by $60 \%$.

The mechanism by which TPC-1 cell growth is inhibited by SU5416 was studied by cell-cycle analysis. Cells treated with $10 \mu \mathrm{M}$ inhibitor for $24 \mathrm{~h}$ showed a marked increase of the G1 peak with a concomitant decrease of the number of cells in S-phase (Fig. 6). No sub-G1 peak was detected, even after $96 \mathrm{~h}$ of exposure to the compound (not shown). By contrast, the pantyrosine kinase inhibitor, staurosporine, induced massive apoptosis as early as $24 \mathrm{~h}$ (data not shown). At the molecular level, SU5416-treated TPC-1 cells showed a remarkable increase of $\mathrm{p} 27 / \mathrm{Kip} 1$ expression, while p21/WAF1 was down-regulated (Fig. 6C). 

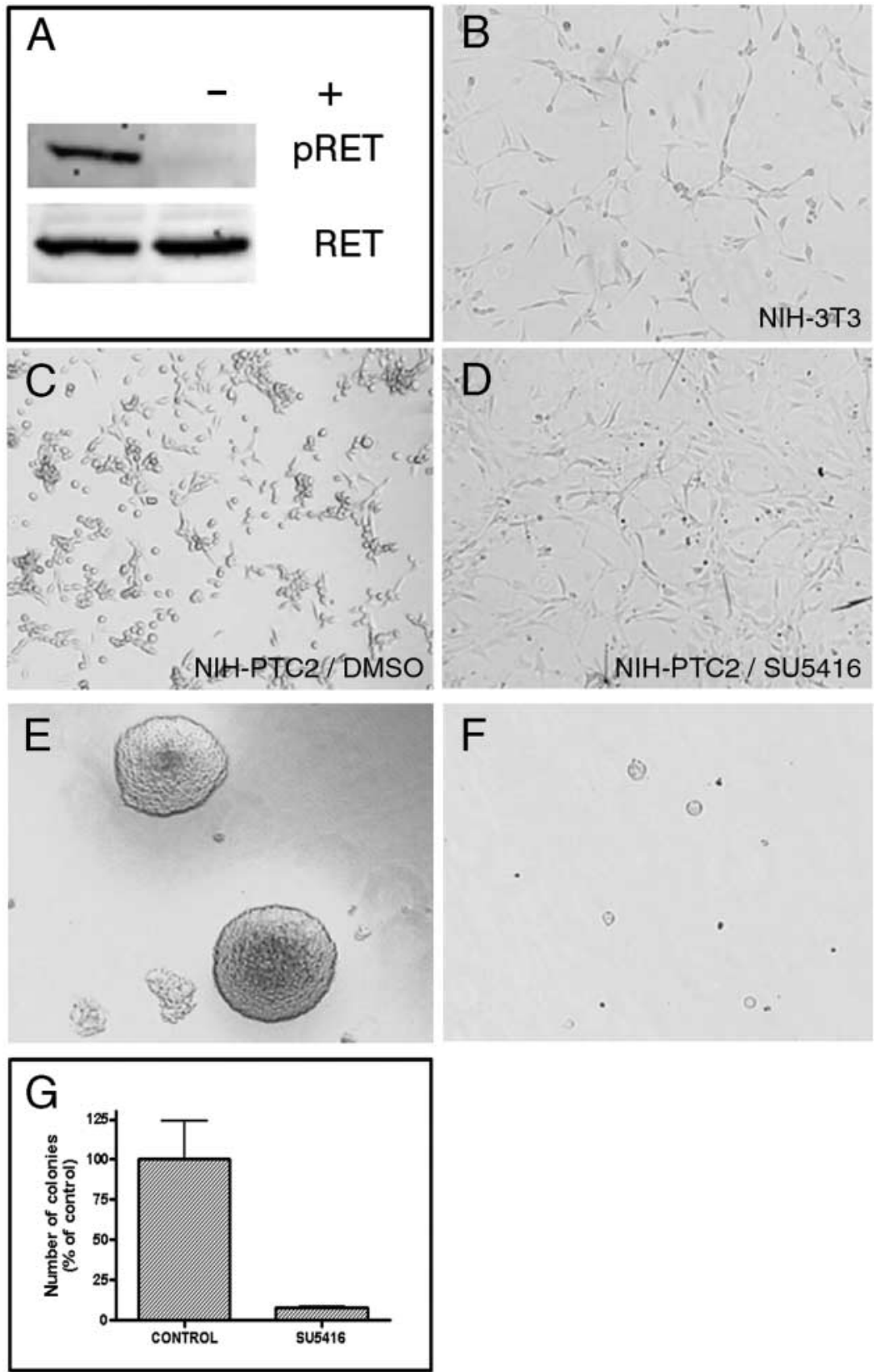

Figure 4 Inhibition of RET-transformed NIH-PTC2 cells: (A) Cells were treated with DMSO (-) or $10 \mu \mathrm{M}$ SU5416 (+) for $4 \mathrm{~h}$ and lysed. Total lysates were run on SDS-PAGE and probed with anti-phospho-RET ${ }^{\mathrm{Y} 905}$ (top panel) and anti-RET (bottom panel) antibodies. Photographs of parental NIH-3T3 cells (B) and NIH-PTC2 cells treated with DMSO (C) or $10 \mu \mathrm{M}$ SU5416 (D) for $48 \mathrm{~h}$. (E)-(G) NIH-PTC2 cells were seeded in soft agar medium without (E) or with $20 \mu \mathrm{M}$ SU5416 (F). After 2 weeks, large colonies were counted and photographed. Percent number of colonies is reported in $(G)$. All pictures were taken at the same magnification.

These results indicate that SU5416 inhibits RETdependent growth and intracellular signaling in human thyroid carcinoma cells and the observed block of proliferation is due to a $\mathrm{G} 1$ arrest, rather than apoptosis.

\section{In vivo modulation of RET autophosphorylation}

To determine whether SU5416 is able to block RET activity in vivo, nude mice were inoculated subcutaneously with NIH-PTC cells. These cells grow as 
A

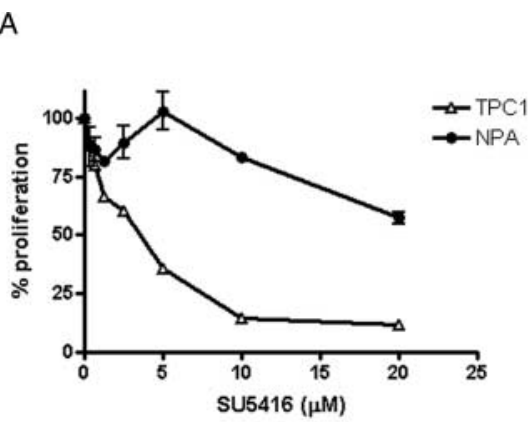

B

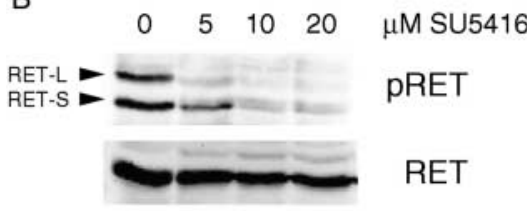

C

RET
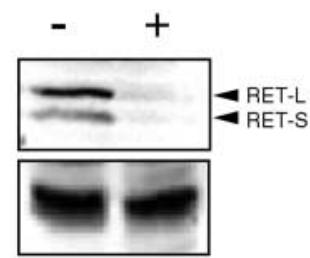

pERK $1 / 2$

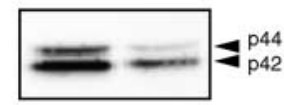

ERK $1 / 2$

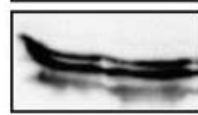

\section{pJNK1/2}

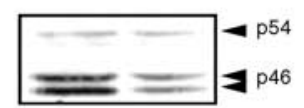

JNK1/2

Figure 5 Inhibition of human PTC cells: (A) Effect of SU5416 on the proliferation rate of TPC-1 (RET-positive) and NPA (RET-negative) thyroid cancer cells; (B) Dose-dependent inhibition of RET phosphorylation in TPC-1 cells. Both RET/PTC1 isoforms are detected by the antibody. Total RET is shown below for loading control. Anti-RET antibody preferentially recognizes the short isoform; (C) TPC-1 cells were treated for $36 \mathrm{~h}$ with DMSO (-) or $25 \mu \mathrm{M} \mathrm{SU5416}(+)$ and lysates probed with the indicated phospho specific and total protein antibodies.

xenograft with high efficiency (Borrello et al. 1996) and formed palpable tumors within 10 days. At day 14 after implantation, tumor-bearing mice were treated with a single dose of inhibitor, or vehicle alone, for $6 \mathrm{~h}$.
Western blot analysis of resected tumors showed that RET autophosphorylation on Tyr 905 was inhibited in treated animals, when compared to control mice (Fig. 7). RET protein levels were left unaffected by the
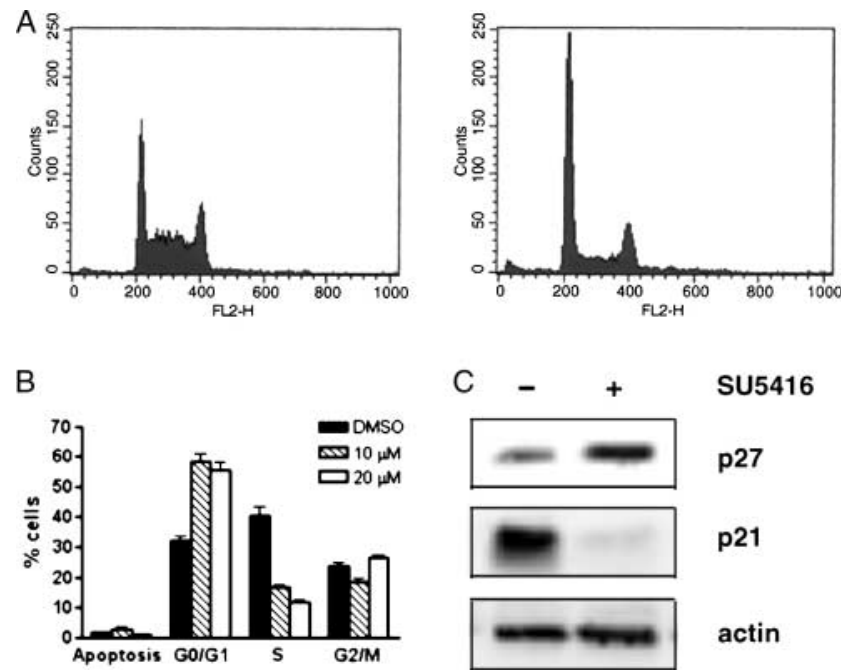

Figure 6 Cell cycle analysis of TPC-1 cells: (A) Representative propidium iodide histograms from DMSO- (left panel) and SU5416-treated (right panel) TPC-1 cells; (B) Graphic representation (mean \pm s.E.M.) of the data from three experiments. After $24 \mathrm{~h}$, control cells exhibited $32 \pm 3 \% \mathrm{GO} / \mathrm{G} 1$ and $40 \pm 5 \%$ S-phase cell populations, while cells treated with $10 \mu \mathrm{M}$ SU5416 showed $58 \pm 4 \%$ G0/G1 and $16 \pm 1 \%$ replicating cells; treatment with $20 \mu \mathrm{M}$ caused a further reduction of S-phase cell number (11 $\pm 1 \%)$; (C) TPC-1 cells were treated as in Fig. 5C; p27 and p21 expression levels were determined by western analysis. Anti-actin blot is showed for loading control. 


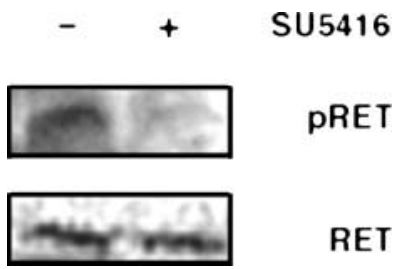

Figure 7 Inhibition of RET activity in mice. Nude mice bearing established tumors were treated with SU5416 i.p. $(50 \mathrm{mg} / \mathrm{kg}$ ) and sacrificed after $6 \mathrm{~h}$. Control mice received DMSO. Western blot analysis was performed on tumor lysates, using anti-phospho-RET (top panel) or anti-RET (bottom panel) antibodies.

treatment. This result indicates that RET catalytic activity was shut down in the tumors and confirms SU5416 as a potent RET inhibitor.

\section{Activity of SU5416 on mutant RET}

Sensitivity of tyrosine kinases to different classes of inhibitors appears to be modulated by a key residue regulating access to the ATP-binding site. For example, replacement of Tyr- 315 of ABL by bulkier residues, such as isoleucine, causes resistance to Imatinib (Gorre et al. 2001). Similarly, PP1 is unable to inhibit $\mathrm{c}-S r c^{\mathrm{T} 341 \mathrm{M}}$ kinase, or oncogenic v-Src, which carries an isoleucine at the corresponding position (Liu et al. 1999). A similar phenomenon was observed for EGFR, FGFR, and PDGFR (Blencke et al. 2004). On the other hand, changing Phe-691 to smaller threonine rendered FLT-3 kinase sensitive to Imatinib (Bohmer et al. 2003). In contrast, three indolinone compounds were found to be insensitive to mutations of this particular residue, suggesting that this class of inhibitors may represent an exception to the rule (Blencke et al. 2004). The corresponding amino acid in wild-type RET is a valine, which is predicted to be small enough to accommodate inhibitors within the ATP pocket. Disease-associated mutations at Val-804 confer resistance to inhibition by PP1, PP2, and ZD6474 (Carlomagno et al. 2004). We expressed RET ${ }^{\mathrm{V} 804 \mathrm{M}}$ mutant in Baculovirus and tested its sensitivity to inhibitors. As expected, mutant RET was resistant to PP1 (Fig. 8A). Surprisingly, SU5416 did not inhibit mutant $\mathrm{RET}^{\mathrm{V} 804 \mathrm{M}}$, 50\% inhibition was not reached at compound concentrations up to $30 \mu \mathrm{M}$ (Fig. 8B). In contrast, SU4984 (Fig. 1), the compound that inhibited FGFR1 ${ }^{\text {V561M }}$ mutant (Blencke et al. 2004), blocked $\mathrm{RET}^{\mathrm{wt}}$ and $\mathrm{RET}^{\mathrm{V} 804 \mathrm{M}}$ with similar $\mathrm{IC}_{50}$ : $1 \cdot 3$ vs $2.6 \mu \mathrm{M}$ (Fig. 8B). The growth of mutant RET $^{\text {V804M }}$-expressing NIH-V804M cells was not affected by SU5416 up to $10 \mu \mathrm{M}$, confirming that SU5416 is incapable of blocking V804M-substituted RET kinase (Fig. 8C). In keeping with this result, phosphorylation of $\operatorname{RET}^{\mathrm{V} 804 \mathrm{M}}$ was not inhibited in these cells (data not shown).

\section{Molecular modeling}

We generated a model of the active RET kinase using the insulin receptor kinase as a template. Molecular
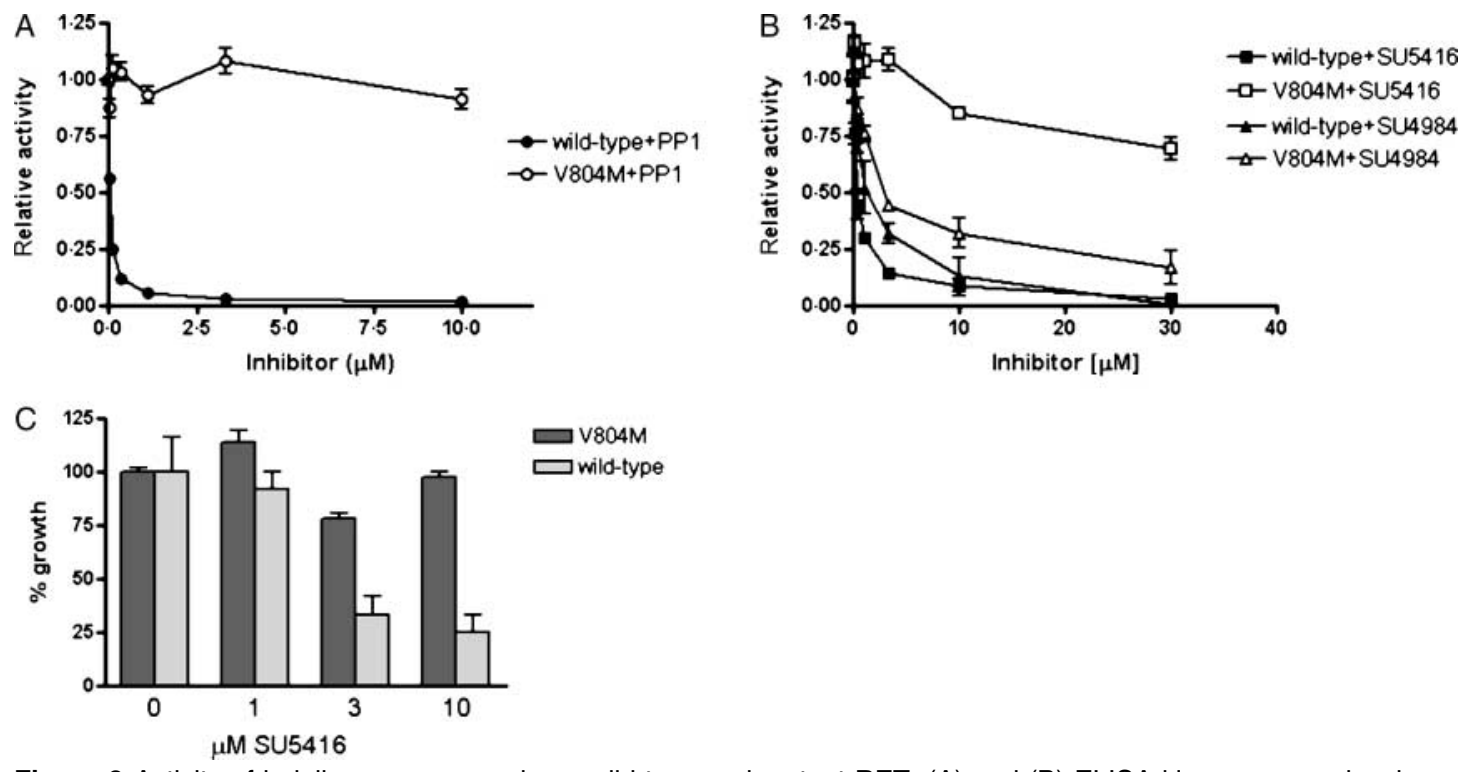

Figure 8 Activity of indolinone compounds on wild-type and mutant RET: (A) and (B) ELISA kinase assay showing dose-response curves of wild-type RET and RET ${ }^{\mathrm{V} 804 \mathrm{M}}$ incubated with PP1 (A) or with SU5416 and the related compound SU4984 (B); (C) NIH-PTC2 (wild type) and NIH-V804M cells were treated with increasing doses of SU5416 for $72 \mathrm{~h}$ and counted. Data are reported as percentage of viable cells compared to untreated control. 
docking of SU4984 within the ATP-binding site of RET (Fig. 9A) revealed an orientation of the compound that corresponds very well with the one observed in the crystal structure of the inhibitor in complex with FGFR1 kinase (Mohammadi et al. 1997). The oxindole core is positioned at the same region as the adenine ring of ATP and makes two hydrogen bonds with the backbone of RET hinge region. The carbonyl oxygen of glutamate- 805 interacts with the indolinone nitrogen, while the amide nitrogen of Ala- 807 is in contact with the oxygen atom of the inhibitor (Fig. 9D). In addition, several hydrophobic residues surround the cavity, contributing to the stabilization of compound binding. The C3 substituent points towards the outside of the pocket. The same binding has been observed for other compounds of the same class (Mohammadi et al. 1997, Moshinsky et al. 2003). This result suggests that our model of RET kinase domain is reliable. Docking of SU5416 showed a similar binding mode, with two hydrogen bonds with the protein backbone (Fig. 9B). When docked on mutant RET ${ }^{\mathrm{V} 804 \mathrm{M}}$, SU5416 could not bind in the same way, because of a clash with Met- 804 . The software did find a docking solution, but the inhibitor was flipped to $180^{\circ}$ with respect to wild-type docking, losing both hydrogen bonds (Fig. 9C). This may explain the resistance to inhibition. The docking of inhibitor SU4984, instead, was only partially affected by the mutation (Fig. 9E). The compound is slightly pushed outwards because of the presence of the bulkier methionine but, while it loses one H-bond (with Glu805), this is compensated by a new interaction between Tyr- 806 and the N1 of the piperazine ring. The conservation of one interaction with the hinge region and the establishment of a new interaction by the phenyl-piperazinyl moiety of SU4984 suggest that its activity on RET mutant kinase should not be significantly reduced.

\section{Specificity of SU5416}

SU5416 was discovered as a VEGFR2 inhibitor, with some activity against PDGFR and no inhibition of EGFR, HER2, and IGF1R (Sun et al. 1998). It was later shown to inhibit FLT-3 and c-Kit tyrosine kinases at nanomolar concentrations (Krystal et al. 2001, Yee et al. 2002), as well as c-Src, MET, FGFR1, and Zap70 at micromolar doses (Sun et al. 2000, Krystal et al. 2001). As for several other kinase inhibitors, initial assumption of selectivity was due to limited experimental testing. Therefore, we sought to enlarge the specificity profile of SU5416 by analyzing its inhibitory activity on a panel of 52 available protein kinases belonging to different classes, at $10 \mu \mathrm{M}$ inhibitor, a concentration that causes $97 \%$ inhibition of RET kinase activity. As reported in Table 2, c-Src was inhibited by approximately $50 \%$, in line with previous reports, while Src-related Lck was
$70 \%$ inhibited. In addition, we found four serine/ threonine kinases that showed less than $10 \%$ residual activity in the presence of the inhibitor, phosphorylase kinase (PHK), the checkpoint kinase Chk2 (Bartkova et al. 2004), the centromere-associated kinase Aurora B, which is often over-expressed in cancer cells (Kanda et al. 2005), and mammalian Ste20-like kinase 2 (MST2), a pro-apoptotic factor (O'Neill et al. 2005). Four other kinases (MAPKAP-K1a and 1b, SGK, and p70S6K) were substantially ( $>80 \%$ ) but not completely inhibited by $10 \mu \mathrm{M}$ SU5416.

\section{Discussion}

We report here the inhibition of RET kinase activity by the small-molecule inhibitor SU5416. SU5416 belongs to the family of 3-substituted indolin-2-one tyrosine kinase inhibitors. Initially described as a selective VEGFR2 (Flk-1/KDR) inhibitor, this compound has later been shown to inhibit other tyrosine kinases, including Kit, Met, and FLT-3. Due to excellent pharmacokinetics, SU5416 has reached clinical testing, mainly as an anti-angiogenic drug. More recently, SU5416 has also been used for experimental therapy of acute myeloid leukemia, because of c-Kit and Flt-3 inhibition.

In a preliminary screening of potential RET inhibitors, we noticed that a couple of indolinone compounds showed good inhibition in vitro, but poor activity in cell culture, largely due to insolubility. We therefore decided to test SU5416 as it shares the same oxindole scaffold and it has already been demonstrated to possess good properties in vivo. SU5416 inhibited RET in cell-free kinase assays at nanomolar doses, comparable to the $\mathrm{IC}_{50}$ values reported for FLT-3 and c-Kit. Our assay confirmed that SU5416 is a potent inhibitor of FLT-3, while it blocks Alk and Abl kinases only at micromolar concentrations. Previous work showed that this compound is inactive against a number of other kinases, such as EGFR, HER2, IGF1R, and weakly inhibits PDGFR. A related molecule, RPI-1, has anti-tumor activity against thyroid carcinoma in mice. In molecular modeling studies, SU5416 docked in RET active site, in the same position as other indolinone compounds that have been crystallized with the related tyrosine kinase, FGFR1. In view of its potency, safety, its good pharmacokinetics, and the fact that it is amenable to chemical modifications, we suggest that SU5416 may be a good lead structure for new, more selective RET inhibitors.

We show inhibition of RET by SU5416 in various model systems, including IL-3-dependent cells, murine fibroblasts, and human PTC cells. RET/PTC-1-expressing TPC-1 cells were selectively growth inhibited, compared to RET-negative PTC cells NPA, which 


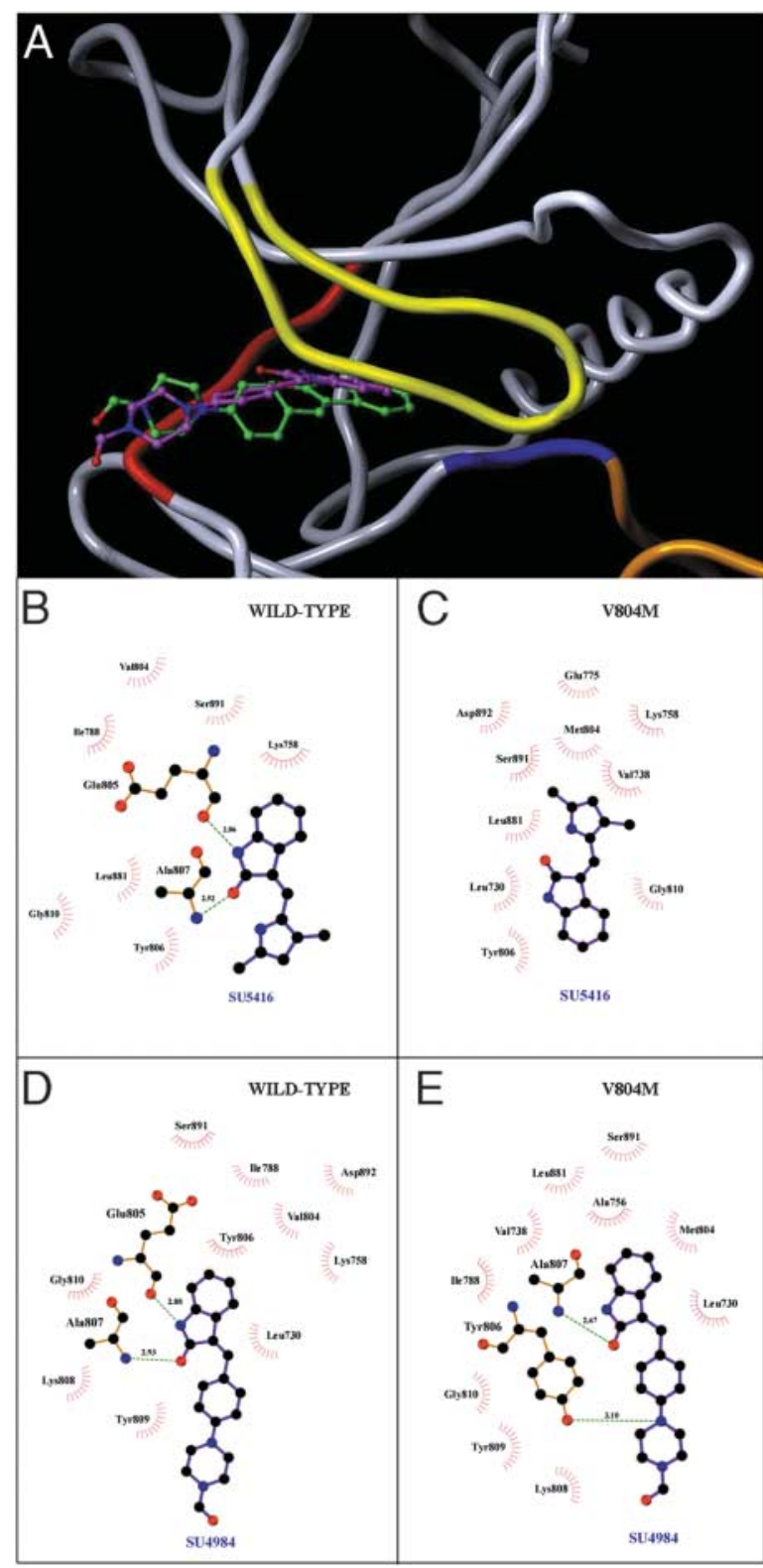

Figure 9 Virtual docking of SU5416 and SU4984 in the active site of RET: (A) Compound SU4984 from the crystal structure of the complex FGFR1-SU4984 (1AGW) (C, magenta; O, red; N, blue) and from GOLD calculation ( $C$, green; $O$, red; $N$, blue) superimposed on the model of RET. The nucleotide binding loop (yellow), the DFG motif (blue), the activation loop (orange) and the hinge region (red) of RET are indicated. Figure generated by Sybyl 7.0 (Anonymous); (B)-(E) schematic representation of SU5416 interactions with models of RET ${ }^{\text {wt }}(B)$ and RET ${ }^{\mathrm{V} 804 \mathrm{M}}(\mathrm{C})$ and SU4984 interactions with RET ${ }^{\mathrm{wt}}(\mathrm{D})$ and RET ${ }^{\mathrm{V} 804 \mathrm{M}}(\mathrm{E})$. Residues forming Van der Waals contacts are indicated; those involved in $\mathrm{H}$-bonding are shown in ball-and-stick representation. $\mathrm{H}$-bonds are shown as dotted lines with distance given in Ångström. Figures generated by LIGPLOT (Wallace et al. 1995). originate from the same cell type as TPC-1 but carry a B-Raf mutation as the primary oncogenic lesion. This result indicates that growth inhibition induced by SU5416 is indeed mediated by RET. Involvement of the VEGFRs can be excluded because NPA cells express these receptors and are not affected by SU5416. The compound was toxic to NPA control cells only at high concentrations, most likely because of the unspecific inhibition of other proliferative pathways. Also, the use of transfected cell lines, such as $\mathrm{NIH}$ and $\mathrm{Ba} / \mathrm{F} 3$, helps to define the role of RET oncogene in mediating SU5416 biological effects; because parental and transfected cells are genetically identical with the exception of the transgene. Growth arrest observed solely in the latter indicates that RET is the relevant target. Blockage of RET autophosphorylation was observed in TPC-1 cells as early as $8 \mathrm{~h}$ and was followed by reduced signaling through the ERK and JNK pathways. RAS/RAF/ERK1/2 pathway is known to be activated by RET both in transfectants and human thyroid carcinoma cell lines, through docking of Shc adaptor proteins to Tyr-1062. JNK1/2 MAPKs are normally involved in stress response and induction of apoptosis. In thyroid tissue, activation of JNKs is instead induced by growth stimuli. Indeed, thyroid carcinoma cells are reported to express high levels of activated JNK, both via Dok-1 phosphorylation and through activation of the small GTPase Cdc42.

Inhibition of RET did not result in apoptosis in TPC1 cells. This data are in line with previous reports, showing no or little evidence of cell death after block of oncogenic RET activity. Either these cells are somewhat resistant to apoptosis and need longer exposure to drugs in order to induce programmed cell death, or the oncogenic activity of RET/PTC is mainly exerted by growth advantage rather than increased survival. Indeed, a multi-step model of thyroid carcinoma is emerging in which RET is a very early event that needs secondary events (such as loss of p53 expression) to establish full-blown aggressive carcinoma (Powell et al. 2001). Cell-cycle arrest induced by SU5416 coincided with a significant up-regulation of the CDK-inhibitor protein p27, in line with a previous report (Vitagliano et al. 2004). Surprisingly, p21 expression was instead down-modulated. The same result was obtained from two independent experiments, using different antibodies. Although we cannot exclude that this effect may be due to unspecific toxicity of the compound, a few cases have been described where p21 repression, rather than induction, correlates with cell-cycle arrest (Noseda et al. 2004, Gartel \& Radhakrishnan 2005).

Activating mutations at Val-804 of RET kinase domain occur both in sporadic and in familial MTC with aggressive behavior and are sometimes associated with a second RET mutation. Importantly, RET ${ }^{\mathrm{V} 804}$ mutants show resistance to kinase inhibitors PP1 and 
Table 2 Residual activity (mean \pm s.D.; percentage of control) of the listed protein kinases in the presence of $10 \mu \mathrm{M}$ SU5416

\begin{tabular}{|c|c|c|c|}
\hline & $\begin{array}{l}\text { Activity } \\
\text { (\% of control) }\end{array}$ & Protein kinase & $\begin{array}{l}\text { Activity } \\
\text { (\% of control) }\end{array}$ \\
\hline \multicolumn{4}{|l|}{$\begin{array}{l}\text { Protein } \\
\text { kinase }\end{array}$} \\
\hline AMPK & $43 \pm 8$ & MSK1 & $38 \pm 4$ \\
\hline Aurora B & $5 \pm 2$ & MST2 & $6 \pm 1$ \\
\hline CAMK-1 & $67 \pm 2$ & NEK2a & $55 \pm 1$ \\
\hline CDK2/cyclin A & $92 \pm 5$ & NEK6 & $91 \pm 8$ \\
\hline $\mathrm{CHK} 1$ & $29 \pm 6$ & NEK7 & $88 \pm 3$ \\
\hline $\mathrm{CHK} 2$ & $7 \pm 2$ & p70 S6K & $19 \pm 1$ \\
\hline CK1 & $21 \pm 4$ & PDK1 & $58 \pm 6$ \\
\hline CK2 & $81 \pm 8$ & PHK & $4 \pm 0$ \\
\hline CSK & $95 \pm 6$ & PIM2 & $94 \pm 2$ \\
\hline DYRK1a & $50 \pm 2$ & PKA & $78 \pm 1$ \\
\hline EFK2 & $80 \pm 1$ & $\mathrm{PKB} \Delta \mathrm{ph}$ & $81 \pm 1$ \\
\hline ERK8 & $55 \pm 3$ & PKBb & $89 \pm 1$ \\
\hline GSK3b & $85 \pm 5$ & PKCa & $99 \pm 7$ \\
\hline $\mathrm{IKKb}$ & $100 \pm 6$ & PKD1 & $43 \pm 0$ \\
\hline JNK/SAPK1C & $86 \pm 2$ & PLK1 & $85 \pm 8$ \\
\hline JNK3 & $75 \pm 1$ & PRAK & $66 \pm 4$ \\
\hline Lck & $27 \pm 5$ & PRK2 & $47 \pm 1$ \\
\hline MAPK2/ERK2 & $73 \pm 1$ & ROCK-II & $59 \pm 2$ \\
\hline MAPKAP-K1a & $12 \pm 3$ & SAPK2a/p38 & $73 \pm 0$ \\
\hline MAPKAP-K1b & $16 \pm 4$ & SAPK2b/p38ß2 & $86 \pm 3$ \\
\hline MAPKAP-K2 & $103 \pm 2$ & SAPK3/p38g & $78 \pm 2$ \\
\hline MAPKAP-K3 & $80 \pm 7$ & SAPK4/p38d & $70 \pm 7$ \\
\hline MARK3 & $31 \pm 2$ & SGK & $14 \pm 4$ \\
\hline MKK1 & $23 \pm 2$ & smMLCK & $23 \pm 4$ \\
\hline MNK1 & $78 \pm 0$ & Src & $51 \pm 4$ \\
\hline MNK2 & $92 \pm 1$ & SRPK1 & $68 \pm 2$ \\
\hline
\end{tabular}

ZD6474 (Carlomagno et al. 2004). We studied the possibility that RET mutant V804M is inhibited by SU5416. We could not detect any significant inhibition at concentrations that block almost $100 \%$ of wild-type RET activity. This result is in contrast with the proposed property of indolinone compounds entering the kinases by carrying bulky gatekeeper residues (Blencke et al. 2004). In their work, Blencke et al. showed that three such compounds inhibited wild-type and mutant kinases with similar potency, although at rather high doses. In our assay, SU5416 did not alter RET R804M $^{\text {VI }}$ activity even at $30 \mu \mathrm{M}$, showing that the rule does not apply to all indolinones. As a control, we tested the compound that showed activity on mutant FGFR1 (SU4984). This inhibitor belongs to the same series of compounds as SU5416, developed by Sun et al. (1998). It has 1-log reduced potency against RET, compared to SU5416, possibly because it exists predominantly as the inactive $E$ isomer (referring to the configuration of the C-3 substituent). It shows broader specificity, as it also inhibits PDGFR and other kinases (Sun et al. 1998). Because of its lower activity and relative lack of specificity, it was not further developed. On the other hand, the compound SU4984 was able to inhibit mutant RET, as it could be predicted by published results (Blencke et al. 2004). This may be explained by our molecular modeling study, showing that, while SU5416 loses hydrogen interactions in the mutant, SU4984 does not. According to our model, the binding of both inhibitors is in fact altered by the V804M substitution, but SU4984 establishes a new H-bond with Tyr-806. However, it should be noted that Tyr-806 is thought to be phosphorylated in fully activated RET (Kawamoto et al. 2004). We do not know whether the enzyme used in our assay is phosphorylated on this particular residue. In this case, the interaction would take place only when the piperazine nitrogen is protonated.

Finally, we described the activity of compound SU5416 on a large panel of protein kinases. New targets of SU5416 were identified, including some serine/ threonine kinases, unrelated to known target tyrosine kinases. This is of interest, not only for biochemical and biological studies on the newly identified targets, but also as a caveat for cell-based studies focused on known targets. In this study, biological effects were always correlated to RET inactivation. Although we cannot rule out the possibility that the observations are at least partially due to off-target effects, in vitro data support the notion that RET is a direct target of SU5416.

In conclusion, we have shown that SU5416 is a potent inhibitor of RET catalytic activity in biochemical and cellular assays and may represent a good starting structure in the search of a selective RET inhibitor.

\section{Acknowledgements}

We thank the Protein Production and Assay Development team of the Division of Transduction Therapy at Dundee, co-ordinated by Hilary Mclauchlan and James Hastie, for providing the protein kinases used in the specificity profile experiment. We are grateful to Dr Stephan W Morris (St Jude Research Hospital, Memphis, TN, USA) for the NPM/ALK-transformed $\mathrm{Ba} / \mathrm{NA}$ cells and to Dr Rocco Piazza (University of Milan-Bicocca, Milan, Italy) for BCR/ABL-transformed $\mathrm{Ba} / \mathrm{BA}$ cells. We thank Dr Rosalind Gunby (University of Milan-Bicocca, Milan, Italy) for kindly providing the ALK-expressing baculovirus, Dr Oriano Marin (University of Padua, Padua, Italy) for the synthesis of the peptides and Dr Monica Rodolfo (National Cancer Institute, Milan, Italy) for providing anti-ERK1/2 and anti-phospho-ERK1/2 antibodies. We also thank Dr Italia Bongarzone (National Cancer Institute, Milan, Italy) for TPC-1 and NPA cells, Dr Maria Grazia Borrello (National Cancer Institute, Milan, Italy) for NIH-PTC2 cells and Prof. Marc Billaud (University of Lyon, France) for the RET ${ }^{\mathrm{V} 804 \mathrm{M}}$ construct used for NIH-3T3 transfections. This work was supported by AIRC, Min. San. Ricerca Finalizzata (2003), CNR, MIUR-COFIN and PRIN programs (2003, 2004), EU (Prokinase 
network, \#503467), CIHR, NCI-C. The authors declare that there is no conflict of interest that would prejudice the impartiality of this scientific work.

\section{References}

Anonymous SYBYL 7.0. Tripos Inc., St. Louis, Missouri, USA.

Bain J, McLauchlan H, Elliott M \& Cohen P 2003 The specificities of protein kinase inhibitors: an update. Biochemical Journal $\mathbf{3 7 1}$ 199-204.

Bartkova J, Guldberg P, Gronbaek K, Koed K, Primdahl H, Moller K, Lukas J, Orntoft TF \& Bartek J 2004 Aberrations of the Chk2 tumour suppressor in advanced urinary bladder cancer. Oncogene 23 8545-8551.

Blencke S, Zech B, Engkvist O, Greff Z, Orfi L, Horvath Z, Keri G, Ullrich A \& Daub H 2004 Characterization of a conserved structural determinant controlling protein kinase sensitivity to selective inhibitors. Chemistry and Biology 11 691-701.

Bohmer FD, Karagyozov L, Uecker A, Serve H, Botzki A, Mahboobi S \& Dove S 2003 A single amino acid exchange inverts susceptibility of related receptor tyrosine kinases for the ATP site inhibitor STI571. Journal of Biological Chemistry 278 5148-5155 (Epub 2002 November 5114).

Borrello MG, Alberti L, Arighi E, Bongarzone I, Battistini C, Bardelli A, Pasini B, Piutti C, Rizzetti MG, Mondellini P et al. 1996 The full oncogenic activity of Ret/ptc2 depends on tyrosine 539, a docking site for phospholipase Cgamma. Molecular and Cellular Biology 16 2151-2163.

Carlomagno F, Vitagliano D, Guida T, Ciardiello F, Tortora G, Vecchio G, Ryan AJ, Fontanini G, Fusco A \& Santoro M $2002 a$ ZD6474, an orally available inhibitor of KDR tyrosine kinase activity, efficiently blocks oncogenic RET kinases. Cancer Research 62 7284-7290.

Carlomagno F, Vitagliano D, Guida T, Napolitano M, Vecchio G, Fusco A, Gazit A, Levitzki A \& Santoro M 2002b The kinase inhibitor PP1 blocks tumorigenesis induced by RET oncogenes. Cancer Research 62 1077-1082.

Carlomagno F, Vitagliano D, Guida T, Basolo F, Castellone MD, Melillo RM, Fusco A \& Santoro M 2003 Efficient inhibition of RET/papillary thyroid carcinoma oncogenic kinases by 4-amino-5(4-chloro-phenyl)-7-(t-butyl)pyrazolo[3,4-d]pyrimidine (PP2). Journal of Clinical Endocrinology and Metabolism 88 1897-1902.

Carlomagno F, Guida T, Anaganti S, Vecchio G, Fusco A, Ryan AJ, Billaud M \& Santoro M 2004 Disease associated mutations at valine 804 in the RET receptor tyrosine kinase confer resistance to selective kinase inhibitors. Oncogene 23 6056-6063.

Case DA, Pearlman DA, Caldwell JW, Cheatham TE, III, Ross WS, Simmerling CL, Darden TA, Merz KM, Stanton RV, Cheng AL et al. 1999 AMBER 6, San Francisco: University of California.

Chiariello M, Visconti R, Carlomagno F, Melillo RM, Bucci C, de Franciscis V, Fox GM, Jing S, Coso OA, Gutkind JS et al. 1998 Signalling of the Ret receptor tyrosine kinase through the c-Jun $\mathrm{NH}_{2-}$ terminal protein kinases (JNKS): evidence for a divergence of the ERKs and JNKs pathways induced by Ret. Oncogene 16 2435-2445.

Coluccia AM, Perego S, Cleris L, Gunby RH, Passoni L, Marchesi E, Formelli F \& Gambacorti-Passerini C 2004 Bcl-XL down-regulation suppresses the tumorigenic potential of NPM/ALK in vitro and in vivo. Blood 103 2787-2794 (Epub 2003 December 2784).

Davies SP, Reddy H, Caivano M \& Cohen P 2000 Specificity and mechanism of action of some commonly used protein kinase inhibitors. Biochemical Journal 351 95-105.

Donella-Deana A, Marin O, Cesaro L, Gunby RH, Ferrarese A, Coluccia AM, Tartari CJ, Mologni L, Scapozza L, GambacortiPasserini C et al. 2005 Unique substrate specificity of anaplastic lymphoma kinase (ALK): development of phosphoacceptor peptides for the assay of ALK activity. Biochemistry 44 8533-8542.
Drosten M \& Putzer BM 2003 Gene therapeutic approaches for medullary thyroid carcinoma treatment. Journal of Molecular Medicine 1414.

Fiedler W, Mesters R, Tinnefeld H, Loges S, Staib P, Duhrsen U, Flasshove M, Ottmann OG, Jung W, Cavalli F et al. 2003 A phase 2 clinical study of SU5416 in patients with refractory acute myeloid leukemia. Blood 102 2763-2767 (Epub 2003 July 2763).

Gambacorti-Passerini C, le Coutre P, Mologni L, Fanelli M, Bertazzoli C, Marchesi E, Di Nicola M, Biondi A, Corneo GM, Belotti D et al. 1997 Inhibition of the ABL kinase activity blocks the proliferation of BCR/ABL + leukemic cells and induces apoptosis. Blood Cells, Molecules and Diseases 23 380-394.

Gartel AL \& Radhakrishnan SK 2005 Lost in transcription: p21 repression, mechanisms, and consequences. Cancer Research 65 3980-3985.

Gimm O 2001 Thyroid cancer. Cancer Letters 163 143-156.

Glade-Bender J, Kandel JJ \& Yamashiro DJ 2003 VEGF blocking therapy in the treatment of cancer. Expert Opinion on Biological Therapy 3 263-276.

Gorre ME, Mohammed M, Ellwood K, Hsu N, Paquette R, Rao PN \& Sawyers CL 2001 Clinical resistance to STI-571 cancer therapy caused by BCR-ABL gene mutation or amplification. Science $\mathbf{2 9 3}$ 876-880 (Epub 2001 June 2021).

Ichihara M, Murakumo Y \& Takahashi M 2004 RET and neuroendocrine tumors. Cancer Letters 204 197-211.

Jones G, Willett P, Glen RC, Leach AR \& Taylor R 1997 Development and validation of a genetic algorithm for flexible docking. Journal of Molecular Biology 267 727-748.

Kadomatsu K, Hagihara M, Akhter S, Fan QW, Muramatsu H \& Muramatsu T 1997 Midkine induces the transformation of NIH3T3 cells. British Journal of Cancer 75 354-359.

Kanda A, Kawai H, Suto S, Kitajima S, Sato S, Takata T \& Tatsuka M 2005 Aurora-B/AIM-1 kinase activity is involved in Ras-mediated cell transformation. Oncogene 1818.

Kantarjian H, Sawyers C, Hochhaus A, Guilhot F, Schiffer C, Gambacorti-Passerini C, Niederwieser D, Resta D, Capdeville R, Zoellner U et al. 2002 Hematologic and cytogenetic responses to imatinib mesylate in chronic myelogenous leukemia. New England Journal of Medicine 346 645-652.

Kawamoto Y, Takeda K, Okuno Y, Yamakawa Y, Ito Y, Taguchi R, Kato M, Suzuki H, Takahashi M \& Nakashima I 2004 Identification of RET autophosphorylation sites by mass spectrometry. Journal of Biological Chemistry 279 14213-14224 (Epub 12004 January 14206).

Krystal GW, Honsawek S, Kiewlich D, Liang C, Vasile S, Sun L, McMahon G \& Lipson KE 2001 Indolinone tyrosine kinase inhibitors block Kit activation and growth of small cell lung cancer cells. Cancer Research 61 3660-3668.

Lanzi C, Cassinelli G, Cuccuru G, Zaffaroni N, Supino R, Vignati S, Zanchi C, Yamamoto M \& Zunino F 2003 Inactivation of Ret/Ptc1 oncoprotein and inhibition of papillary thyroid carcinoma cell proliferation by indolinone RPI-1. Cellular and Molecular Life Sciences 60 1449-1459.

Liu Y, Bishop A, Witucki L, Kraybill B, Shimizu E, Tsien J, Ubersax J, Blethrow J, Morgan DO \& Shokat KM 1999 Structural basis for selective inhibition of Src family kinases by PP1. Chemistry and Biology 6 671-678.

Mohammadi M, McMahon G, Sun L, Tang C, Hirth P, Yeh BK, Hubbard SR \& Schlessinger J 1997 Structures of the tyrosine kinase domain of fibroblast growth factor receptor in complex with inhibitors. Science 276 955-960.

Mologni L, Sala E, Riva B, Cesaro L, Cazzaniga S, Redaelli S, Marin O, Pasquato N, Donella-Deana A \& Gambacorti-Passerini C 2005 Expression, purification, and inhibition of human RET tyrosine kinase. Protein Expression and Purification 41 177-185.

Moshinsky DJ, Bellamacina CR, Boisvert DC, Huang P, Hui T, Jancarik J, Kim SH \& Rice AG 2003 SU9516: biochemical analysis of cdk inhibition and crystal structure in complex with cdk2. Biochemical and Biophysical Research Communications 310 1026-1031. 
Nikiforov YE, Rowland JM, Bove KE, Monforte-Munoz H \& Fagin JA 1997 Distinct pattern of ret oncogene rearrangements in morphological variants of radiation-induced and sporadic thyroid papillary carcinomas in children. Cancer Research 57 1690-1694.

Noseda M, Chang L, McLean G, Grim JE, Clurman BE, Smith LL \& Karsan A 2004 Notch activation induces endothelial cell cycle arrest and participates in contact inhibition: role of p21Cip1 repression. Molecular and Cellular Biology 24 8813-8822.

O'Neill EE, Matallanas D \& Kolch W 2005 Mammalian sterile 20-like kinases in tumor suppression: an emerging pathway. Cancer Research 65 5485-5487.

Parthasarathy R, Cote GJ \& Gagel RF 1999 Hammerhead ribozymemediated inactivation of mutant RET in medullary thyroid carcinoma. Cancer Research 59 3911-3914.

Piazza RG, Magistroni V, Gasser M, Andreoni F, Galietta A, Scapozza L \& Gambacorti-Passerini C 2005 Evidence for D276G and L364I Bcr$\mathrm{Abl}$ mutations in $\mathrm{Ph}+$ leukaemic cells obtained from patients resistant to Imatinib. Leukemia 19 132-134.

Powell DJ, Jr, Russell JP, Li G, Kuo BA, Fidanza V, Huebner K \& Rothstein JL 2001 Altered gene expression in immunogenic poorly differentiated thyroid carcinomas from RET/PTC3p53-/- mice. Oncogene 20 3235-3246.

Powell DJ, Jr, Eisenlohr LC \& Rothstein JL 2003 A thyroid tumorspecific antigen formed by the fusion of two self proteins. Journal of Immunology 170 861-869.

Putzer BM \& Drosten M 2004 The RET proto-oncogene: a potential target for molecular cancer therapy. Trends in Molecular Medicine $\mathbf{1 0}$ 351-357.

Santoro M, Carlomagno F, Melillo RM \& Fusco A 2004 Dysfunction of the RET receptor in human cancer. Cellular and Molecular Life Sciences 61 2954-2964.

Strock CJ, Park JI, Rosen M, Dionne C, Ruggeri B, Jones-Bolin S, Denmeade SR, Ball DW \& Nelkin BD 2003 CEP-701 and CEP-751 inhibit constitutively activated RET tyrosine kinase activity and block medullary thyroid carcinoma cell growth. Cancer Research 63 5559-5563.

Sun L, Tran N, Tang F, App H, Hirth P, McMahon G \& Tang C 1998 Synthesis and biological evaluations of 3-substituted indolin-2-ones: a novel class of tyrosine kinase inhibitors that exhibit selectivity toward particular receptor tyrosine kinases. Journal of Medicinal Chemistry 41 2588-2603.

Sun L, Tran N, Liang C, Hubbard S, Tang F, Lipson K, Schreck R, Zhou Y, McMahon G \& Tang C 2000 Identification of substituted 3[(4,5,6, 7-tetrahydro-1H-indol-2-yl) methylene $]$-1,3-dihydroindol-2ones as growth factor receptor inhibitors for VEGF-R2 (Flk1/KDR), FGF-R1, and PDGF-Rbeta tyrosine kinases. Journal of Medicinal Chemistry 43 2655-2663.

Vitagliano D, Carlomagno F, Motti ML, Viglietto G, Nikiforov YE, Nikiforova MN, Hershman JM, Ryan AJ, Fusco A, Melillo RM et al. 2004 Regulation of p27Kip1 protein levels contributes to mitogenic effects of the RET/PTC kinase in thyroid carcinoma cells. Cancer Research 64 3823-3829.

Wallace A, Laskowski R \& Thornton J 1995 LIGPLOT: a program to generate schematic diagrams of protein-ligand interactions. Protein Engineering 8 127-134.

Wang SY, Chen B, Zhan YQ, Xu WX, Li CY, Yang RF, Zheng H, Yue PB, Larsen SH, Sun HB et al. 2004 SU5416 is a potent inhibitor of hepatocyte growth factor receptor (c-Met) and blocks HGF-induced invasiveness of human HepG2 hepatoma cells. Journal of Hepatology 41 267-273.

Yee KW, O'Farrell AM, Smolich BD, Cherrington JM, McMahon G, Wait CL, McGreevey LS, Griffith DJ \& Heinrich MC 2002 SU5416 and SU5614 inhibit kinase activity of wild-type and mutant FLT3 receptor tyrosine kinase. Blood 100 2941-2949.

Received in final form 25 May 2006

Accepted 6 June 2006 